\title{
EVALUASI PENAMBAHAN JUMLAH LANTAI PADA GEDUNG PERKULIAHAN FAKULTAS TEKNIK UNIVERSITAS JEMBER
}

\author{
Hari Subagio $^{1)}$, Krisnamurti' ${ }^{1)}$, dan Paksitya Purnama Putra ${ }^{1)}$ \\ 1) Jurusan Teknik Sipil, Universitas Jember, Jember, Jawa Timur \\ subagiohari7@gmail.com
}

\begin{abstract}
Learning facilities for students of the Faculty of Engineering, University of Jember (FT-UNEJ) were still insufficient. Fifteen study programs at FT-UNEJ were only served in one lecture building. Additional floors in existing buildings are done to increase the classrooms as a follow to the problem. An additional three floors were made as a classroom and one roof as a meeting room (rooftop). Planning and evaluation were done by modeling $3 D$ buildings in a structural analysis program. Analysis and evaluation in the structural analysis program were modeled with the same dimensions as the existing conditions, and an additional number of floors would be added according to the preliminary design calculations. Modeling results showed the condition of the building plans was still safe. The largest inter-floor deviation value is $10.2 \mathrm{~mm}$ which is still below the permit deviation (31.5 $\mathrm{mm}$ ), and the structural integrity value is -0.97 (requirement $-1<-0.97<1$ ).
\end{abstract}

Keywords: floor addition, the intersection between floors, structural integrity

\begin{abstract}
ABSTRAK
Sarana pembelajaran untuk mahasiswa Fakultas Teknik Universitas Jember masih kurang tercukupi. Lima belas program studi pada Fakultas Teknik UNEJ hanya dilayani dalam satu gedung perkuliahan. Salah satu solusi untuk permasalahan tersebut ialah dengan menambahkan jumlah lantai pada gedung eksisting untuk memperbanyak jumlah ruang kelas. Penambahan dilakukan sejumlah 3 lantai sebagai ruang kelas dan 1 lantai atap sebagai ruang pertemuan (rooftop). Perencanaan dan evaluasi dilakukan dengan memodelkan gedung secara 3D pada sebuah program analisis struktur. Analisis dan evaluasi pada program analisis struktur dimodelkan dengan dimensi yang sama dengan kondisi eksisting dan akan dilakukan penambahan jumlah lantai dengan dimensi sesuai perhitungan preliminari desain. Hasil pemodelan menujukkan kondisi gedung rencana masih aman. Nilai simpangan antar lantai terbesar adalah $10.2 \mathrm{~mm}$ yang masih di bawah simpangan ijin (31.5 mm), dan nilai integritas struktur sebesar -0.97 (syarat $-1<-0.97<$ 1).
\end{abstract}

Kata kunci: penambahan lantai, simpangan antar lantai, integritas struktur 


\section{PENDAHULUAN}

Fakultas Teknik Universitas Jember masih minim infrastuktur dengan 1 gedung perkuliahan dan 15 program studi, sehingga kurang efektif dalam mengatur jadwal perkuliahan. Pembangunan gedung di area Fakultas Teknik hanya sebatas gedung laboratorium, bukan gedung perkuliahan yang lebih mendesak. Oleh karena itu, Fakultas Teknik perlu penambahan ruang kelas untuk mempermudah kegiatan pembelajaran.

Penambahan ruang kelas ini nantinya akan menambah jumlah lantai gedung tersebut. Kemungkinan kegagalan struktur akan terjadi seiring dengan pertambahan jumlah lantainya. Kegagalan struktur yang dimaksudkan adalah rusaknya struktur balok dan kolom, dalam hal ini kolom menempati posisi yang cukup penting sehingga harus direncanakan dengan prinsip strong column weak beam. Menurut Krisnamurti, Wiswamitra, \& Kriswardana (2013), kolom merupakan elemen struktur yang berfungsi untuk meneruskan gaya gaya dalam dari pelat dan balok yang selanjutnya diteruskan ke pondasi dan tanah dasar. Menurut Irawan (2012), kegagalan struktur kolom akan mengakibatkan runtuhnya secara langsung seluruh komponen struktur dari bangunan gedung.
Melihat kerusakan struktur yang mungkin akan terjadi, maka perlu dilakukan perbaikan struktur kolom eksisting agar dapat diketahui kolom tersebut apakah sudah mampu menahan beban akibat pertambahan lantai tersebut. Salah satu perbaikan yang dapat dilakukan pada kegagalan struktur kolom adalah dengan menggunakan metode jacketing beton. Menurut Soenaryo, Hidayat, \& Siswanto (2009), jacketing beton adalah perbesaran yang dilakukan pada dimensi penampang dan penambahan jumlah tulangan struktur beton bertulang. Berdasarkan permasalahan di atas, maka akan dilakukan pemodelan yang nantinya akan mengevaluasi bagaimana kodisi gedung eksisting (3 lantai) dengan gedung rencana akibat penambahan lantai (6 lantai) dan tidak meninjau kapasitas struktur pondasi.

\section{KAJIAN PUSTAKA}

\subsection{Preliminari Desain}

Digunakan SNI 2847:2019

Persyaratan Beton Struktural untuk Bangunan Gedung dan Penjelasannya sebagai acuan awal pendimensian. Perencanaan dilakukan dengan kemudahan pekerjaan pelaksanaan di lapangan yaitu, sedapat mungkin ukuran kolom disamakan atau variasinya dibuat minimal dengan mutu beton dan jumlah tulangan yang diturunkan pada lantai yang lebih tinggi. 


\subsection{Pembebanan}

Struktur gedung harus mampu menahan beban-beban yang terjadi padanya. Pembebanan yang digunakan mengacu pada SNI 1727:2013 Beban Minimum untuk Perancangan Bangunan Gedung dan Struktur Lain, sedangkan untuk ketahanan terhadap gempa sebuah bangunan harus direncanakan berdasarkan SNI 1726:2019 Tata Cara Perencanaan Ketahanan Gempa untuk Struktur Bangunan Gedung dan Non Gedung (Anonim, 2019a). Semua beban harus dihitung dengan kombinasi pembebanan yang berlaku.

\subsection{Perbaikan Struktur dengan Metode Jacketing Beton}

Menurut Octora (2019), metode jacketing beton merupakan metode perkuatan struktur untuk merekayasa penampang beton sehingga menambah kuat aksial dan daktilitasnya. Tujuan dari metode ini adalah untuk menambah dimensi penampang dari beton sehingga menambah kekuatan aksial dan geser struktur beton. Selain menghitung elemen struktur yang terbebani akibat beban eksisting, pada analisis tegangan juga harus dihitung dengan memodifikasi nilai regangan awal akibat beban eksisting.

\subsection{Integritas Struktur}

Integritas struktur adalah kemampuan dari beberapa komponen struktur untuk menahan gaya akibat berat atau beban yang bekerja pada struktur tersebut ataupun beban dari struktur itu sendiri, dengan tanpa merusak ataupun merusak secara berlebihan dari struktur tersebut.

Menurut Saruni, Dapas, \& Manalip (2017), keruntuhan pada satu kolom yang merupakan elemen tekan dapat mengakibatkan collapse (runtuhnya) pada lantai yang tepat berada di atasnya, dan juga runtuh batas total (ultimate total change) seluruh struktur. Pemeriksaan kekuatan kolom yang direncanakan dapat dilakukan dengan menganalisis struktur dengan rasio tegangan (stress ratio) dari penampang kolom. Analisis ini akan menunjukkan perbandingan antara gaya yang harus didukung kolom rencana dengan kemampuan daya dukung penampang kolom. Menurut Arfiadi (2016), rasio tegangan dapat dihitung dengan rumus 1 sampai 4 berikut:

$$
\begin{aligned}
& -1 \leq \Psi^{\prime} \leq 1 \\
& \Psi^{\prime}=\frac{600}{\mathrm{f}_{\mathrm{y}}}\left(1-\frac{1+\mu}{2 \xi}\right) \\
& \xi=\frac{\mathrm{c}}{\mathrm{h}} \\
& \mu=\frac{h-2 d^{\prime}}{h} \text {. }
\end{aligned}
$$

dengan:

$$
\Psi^{\prime}=\text { Rasio tegangan kolom }
$$




$$
\begin{aligned}
\mathrm{f}_{\mathrm{y}}= & \text { Tegangan leleh baja }(\mathrm{MPa}) \\
\mu= & \text { koefisien friksi } \\
\xi= & \text { Faktor tergantung waktu } \\
& \text { untuk beban tetap } \\
\mathrm{h}= & \text { penampang kolom }(\mathrm{mm})
\end{aligned}
$$

\section{METODE PENELITIAN}

\subsection{Metode Analisis}

Program bantu digunakan untuk memodelkan bangunan gedung sehingga bisa diketahui gaya-gaya dalam yang dibutuhkan untuk mendesain struktur tambahan maupun perbaikannya. Analisis program bantu ini menggunakan metode elemen hingga (FEM) baik untuk static analysis maupun dinamic analisys (nonlinier analisis). Alur pemodelan akan dapat dilihat pada Gambar 1.

Pada penelitian ini akan dilakukan pemodelan gedung eksisting Fakultas Teknik UNEJ yang memiliki 3 lantai, dengan denah struktur yang tipikal dari lantai bawah sampai paling atas. Pemodelan dilakukan dengan program bantu. Mutu beton yang digunakan adalah $25 \mathrm{Mpa}$, dan 40 Mpa untuk dinding geser. Sedangkan mutu baja adalah BJ 37 dan BJ 41. Denah dan data eksisting gedung perkuliahan Fakultas Teknik dapat dilihat pada Gambar 2 dan Tabel 1.

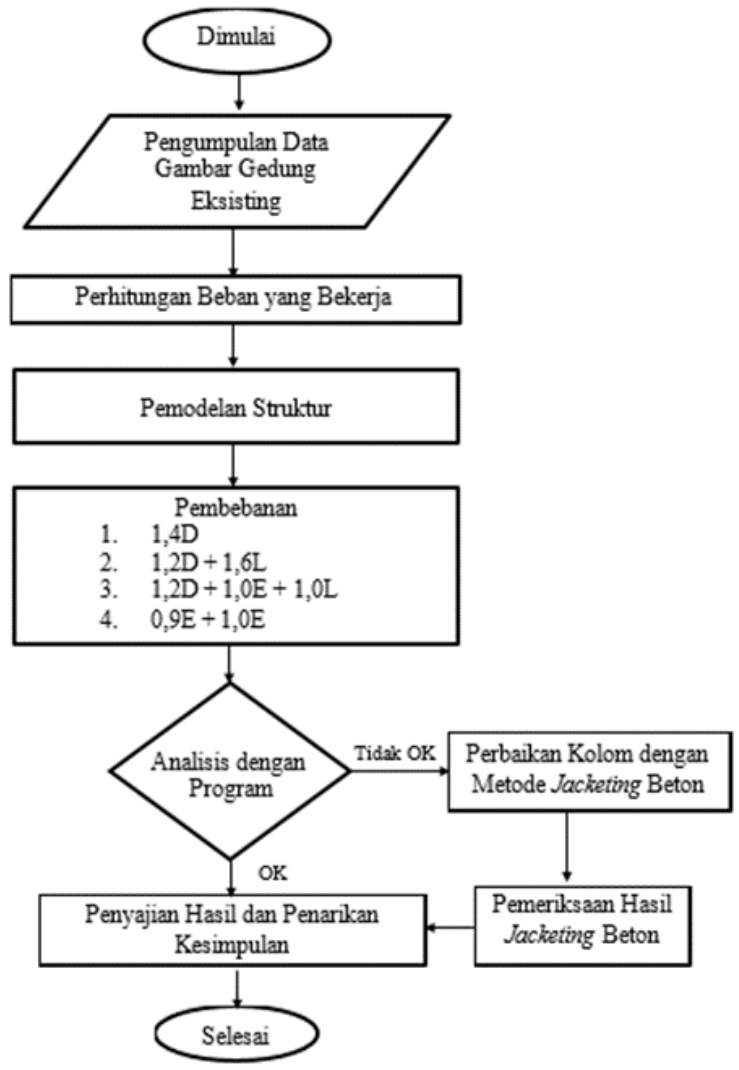

Gambar 1. Alur Pemodelan

Pada tahap selanjutnya dilakukan perhitungan preliminari desain untuk penambahan lantai dengan mengacu perumusan yang tertera pada SNI 28472019, Persyaratan Beton Struktural untuk Bangunan Gedung dan Penjelasannya (Anonim, 2019b). Desain gedung rencana memiliki dinding geser untuk menopang konstruksi lift, tiga lantai baru untuk ruang kelas, serta satu lantai atap untuk pertemuan. Penambahan tiga lantai baru didasarkan dari perhitungan kapasitas kebutuhan ruang kelas Fakultas Teknik UNEJ saat ini. Berikut merupakan desain rencana gedung Perkuliahan Fakultas Teknik yang dapat dilihat pada Gambar 3. 


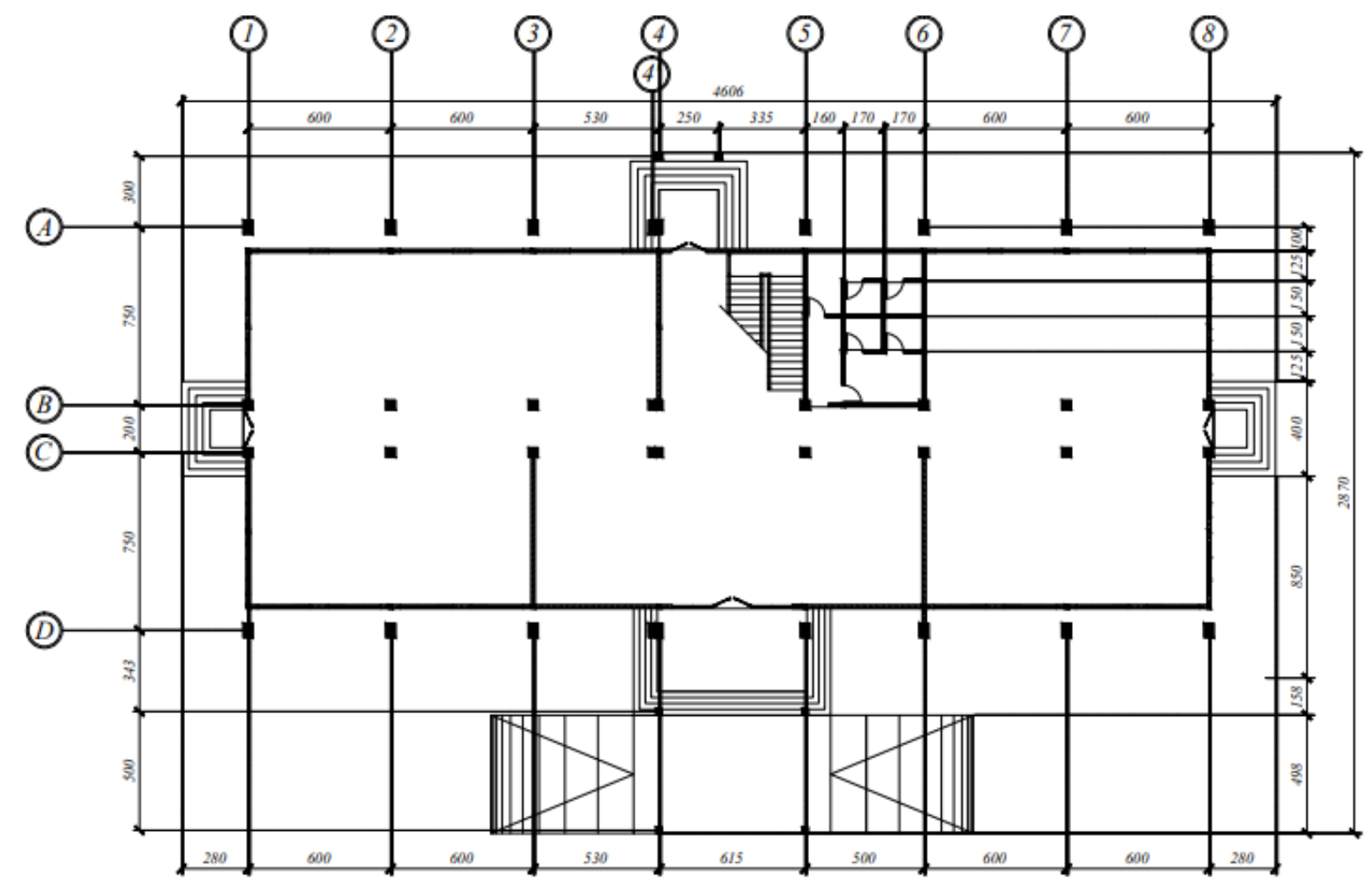

Gambar 2. Denah Eksisting Gedung Perkuliahan Fakultas Teknik UNEJ

Tabel 1. Data Eksisting Balok Gedung

\begin{tabular}{cccccc}
\hline \multirow{2}{*}{ No } & \multirow{2}{*}{ Struktur } & \multicolumn{2}{c}{ Dimensi (mm) } & \multicolumn{2}{c}{ Tulangan } \\
\cline { 3 - 6 } & & $\mathrm{P}$ & $\mathrm{L}$ & Tumpuan & Lapangan \\
\hline 1 & Balok 1 & 300 & 650 & 8D22 & 2D22 \\
2 & Balok 2 & 300 & 600 & 8D22 & 2D22 \\
3 & Balok 3 & 300 & 500 & 7D16 & 2D16 \\
4 & Balok 4 & 200 & 400 & 3D14 & 2D14 \\
5 & Balok 5 & 300 & 400 & 2D22 & 2D22 \\
6 & Balok 6 & 200 & 300 & 3D14 & 2D14 \\
7 & Balok 7 & 150 & 200 & 3D10 & 2D10 \\
8 & Balok 8 & 200 & $300-450$ & 6D16 & 2D16 \\
\hline
\end{tabular}

Tabel 2. Data Eksisting Kolom Gedung

\begin{tabular}{cccccc}
\hline \multirow{2}{*}{ No } & \multirow{2}{*}{ Struktur } & \multicolumn{2}{c}{ Dimensi $(\mathrm{mm})$} & \multicolumn{2}{c}{ Tulangan } \\
\cline { 3 - 6 } & & $\mathrm{P}$ & $\mathrm{L}$ & Longitudinal & Sengkang \\
\hline 1 & Kolom 1 & 400 & 600 & 8D22 & P10-200 \\
2 & Kolom 2 & 300 & 600 & 8D19 & P10-200 \\
3 & Kolom 3 & 400 & 400 & 8D19 & P10-200 \\
4 & Kolom 4 & 400 & 300 & 8D14 & P10-200 \\
5 & Kolom 5 & 300 & 300 & 8D14 & P8-200 \\
\hline
\end{tabular}




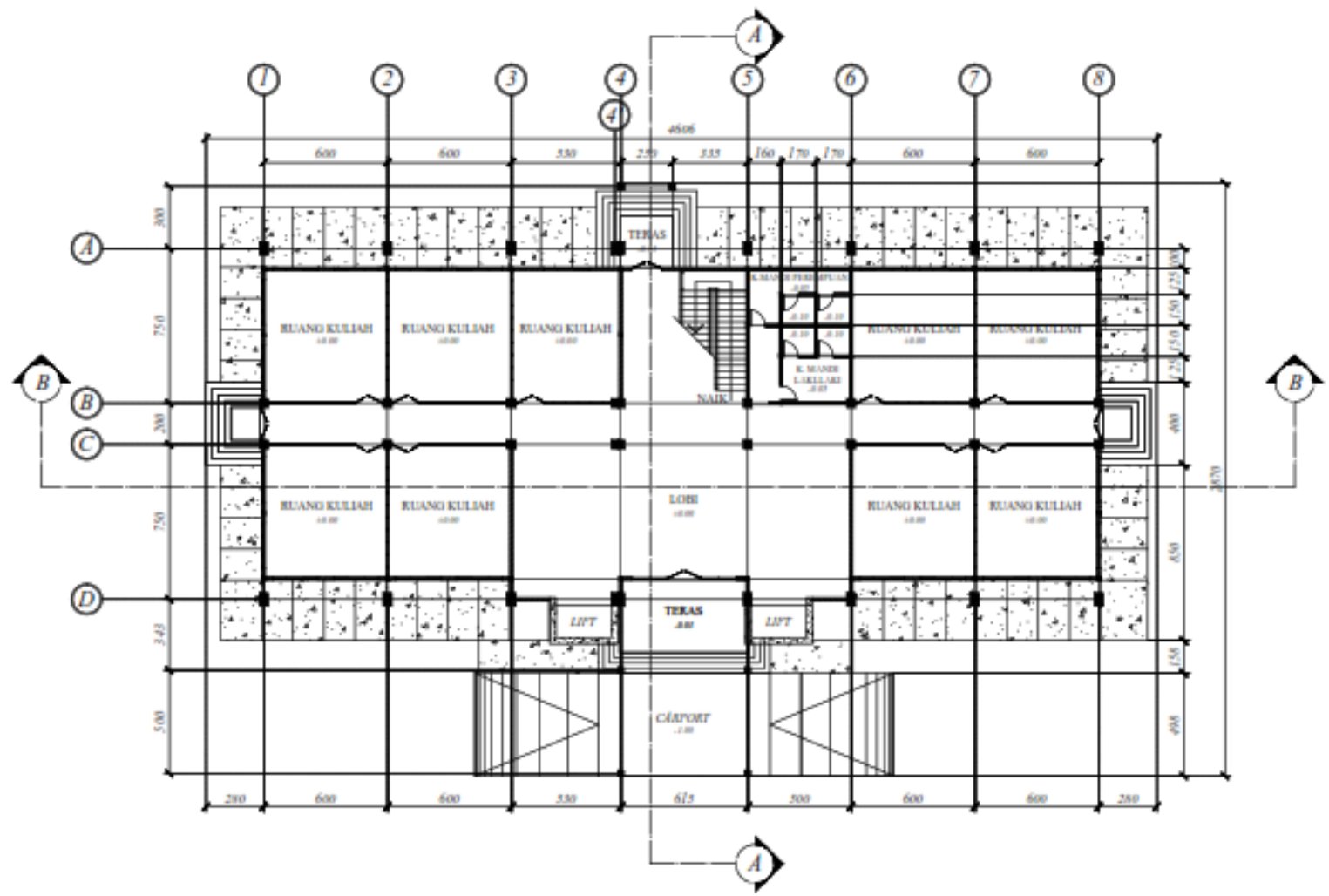

Gambar 3. Denah Rencana Gedung Perkuliahan Fakultas Teknik UNEJ

\subsection{Jacketing Beton}

Jacketing beton dilakukan dengan menambah dimensi kolom sekaligus menambah jumlah tulangan yang telah ada. Pemeriksaan kapasistas kolom rencana dilakukan dengan memodelkannya dilakukan untuk memeriksa kekuatan kolom apakah sudah mampu menahan beban. Perkuatan dengan metode jacketing beton ini cukup efektif dalam meningkatkan kuat geser kolom dan aksial kolom.

\section{HASIL DAN PEMBAHASAN}

\subsection{Preliminari Desain}

Preliminari desain digunakan untuk menentukan dimensi sementara struktur baru untuk penambahan lantai yang nantinya akan dimodelkan dengan menggunakan program bantu analisis struktur. Peliminari desain meliputi pelat lantai, pelat atap sebagai ruang terbuka, balok, kolom dan dinding geser. Hasil perhitungan preliminari desain untuk struktur balok dan kolom yang dapat dilihat pada Tabel 3 dan 4. Hasil perhitungan lainnya adalah, pelat dengan tebal $135 \mathrm{~mm}$ dan dinding geser dengan tebal $300 \mathrm{~mm}$.

Kemudian, dilakukan perhitungan pembebanan yang mengacu pada SNI 1727-2013, Beban Minimum untuk Perancangan Bangunan Gedung dan Struktur Lain. Setiap segmen dilakukan 
perhitungan pembebanan yang meliputi beban mati tambahan (super imposed dead load/SIDL), beban mati (dead load/DL), beban hidup (live load/LL), dan beban atap sebagai ruang pertemuan (Anonim, 2013).

\section{Tabel 3. Hasil Preliminari Desain Balok}

\begin{tabular}{|c|c|c|c|c|}
\hline \multirow{2}{*}{ No } & \multirow{2}{*}{ Simbol } & \multirow{2}{*}{$\begin{array}{c}\text { Bentang } \\
(\mathrm{mm})\end{array}$} & \multicolumn{2}{|c|}{ Dimensi $(\mathrm{mm})$} \\
\hline & & & $\mathrm{L}$ & $\mathrm{T}$ \\
\hline 1 & B1 & 7500 & 350 & 550 \\
\hline 2 & B2 & 7500 & 300 & 500 \\
\hline 3 & B3 & 6000 & 300 & 450 \\
\hline 4 & B4 & 5700 & 200 & 400 \\
\hline 5 & B5 & 2000 & 150 & 250 \\
\hline 6 & B6 & 3750 & 200 & 300 \\
\hline 7 & B7 & 1200 & 125 & 200 \\
\hline 8 & B8 & 1650 & 150 & 250 \\
\hline 9 & BD1 & 7500 & 250 & 400 \\
\hline 10 & BD2 & 2000 & 125 & 200 \\
\hline
\end{tabular}

Tabel 4. Hasil Preliminari Desain Kolom

\begin{tabular}{cccc}
\hline \multirow{2}{*}{ No } & \multirow{2}{*}{ Simbol } & \multicolumn{2}{c}{ Dimensi $(\mathrm{mm})$} \\
\cline { 3 - 4 } & & $\mathrm{P}$ & $\mathrm{L}$ \\
\hline 1 & K1 & 300 & 400 \\
2 & K2 & 300 & 350 \\
\hline
\end{tabular}

\subsection{Pemodelan Struktur}

Pemodelan dilakukan dengan membuat material dan section properties untuk setiap struktur yang digunakan nantinya. Dimensi section properties disesuaikan dengan hasil dari preliminari desain. Tahap selanjutnya adalah memasukkan beban-beban yang akan digunakan meliputi beban mati tambahan (SIDL), beban hidup (LL) untuk ruang kelas dan ruang pertemuan dan juga beban gempa. Berdasarkan SNI 1726-2019, Tata Cara Perencanaan Ketahanan Gempa untuk Struktur Bangunan Gedung dan Non Gedung untuk wilayah Kabupaten jember memiliki nilai parameter Ss terbesar $1.2 \mathrm{~g}$ dan untuk $\mathrm{S}_{1}$ terbesar $0.5 \mathrm{~g}$ yang dapat dilihat pada Gambar 4 dan 5.

Pemodelan awal dilakukan terhadap eksisting dari gedung itu sendiri yang kemudian dilanjutkan dengan pemodelan gedung rencana. Hasil pemodelan gedung eksisting dapat dilihat pada Gambar 6.

Hasil analisis menunjukkan struktur eksisting dalam kondisi aman, hal ini dapat dilihat dari warna frame (rangka struktur) yang menunjukkan warna hijau dan biru dengan arti masih mampu menahan beban yang diterimanya.

Pemodelan dilanjutkan sesuai dengan desain gedung rencana yakni penambahan tiga struktur lantai dan atap serta dinding geser.yang dapat dilihat pada Gambar 7 dan 8. Dilihat dari warna frame hijau dan biru tersebut maka hasil pemodelan juga menunjukkan bahwa desain gedung rencana mampu menahan gaya akibat perencanaan penambahan lantai. Untuk selanjutnya tingkat keamanan gedung dianalisis dengan meninjau nilai simpangan antar lantai yang terjadi pada gedung rencana. 


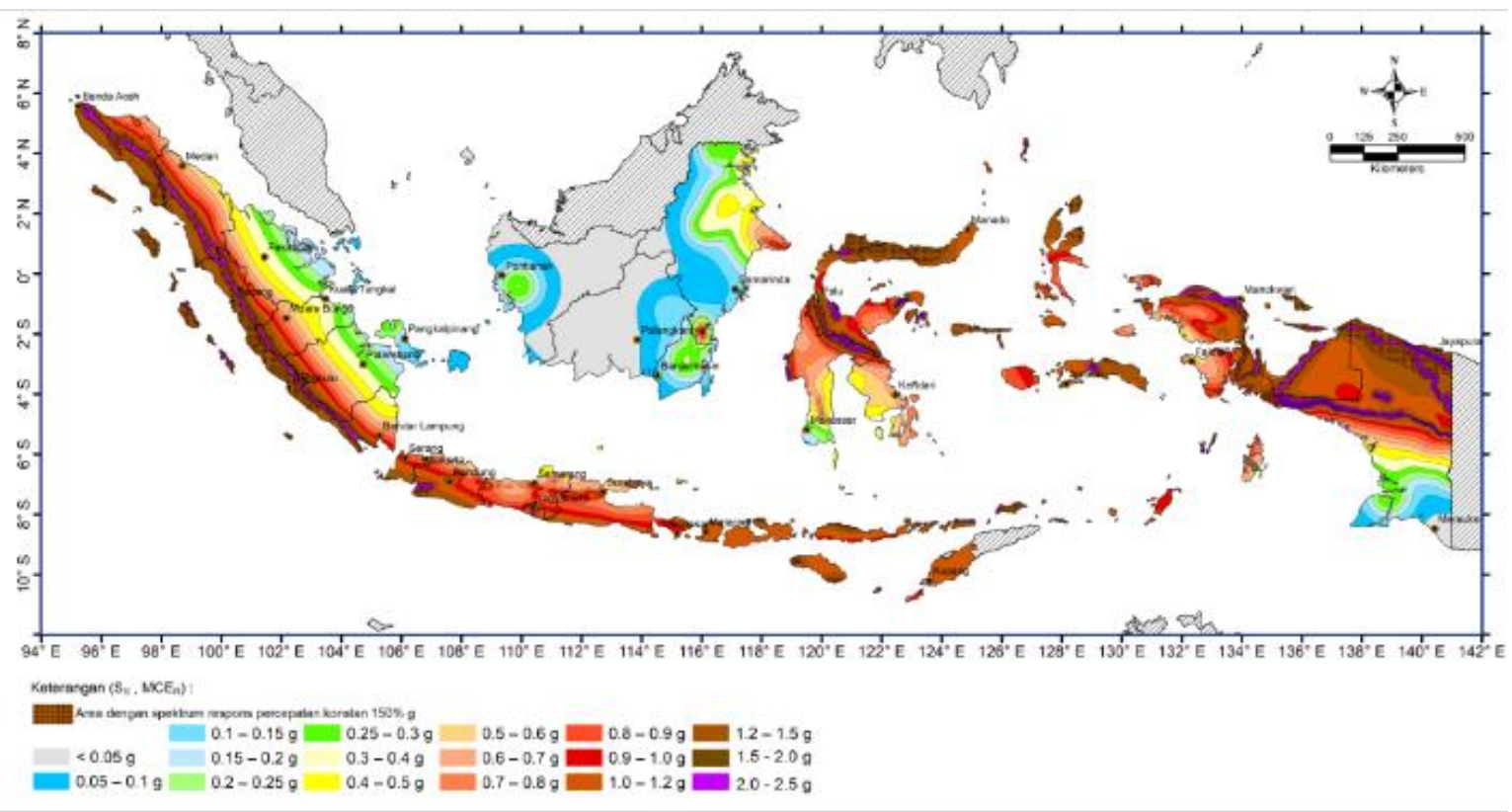

Gambar 4. Peta MCR-E periode pendek ( $T=0,2$ detik)

(Sumber: Anonim, 2012)

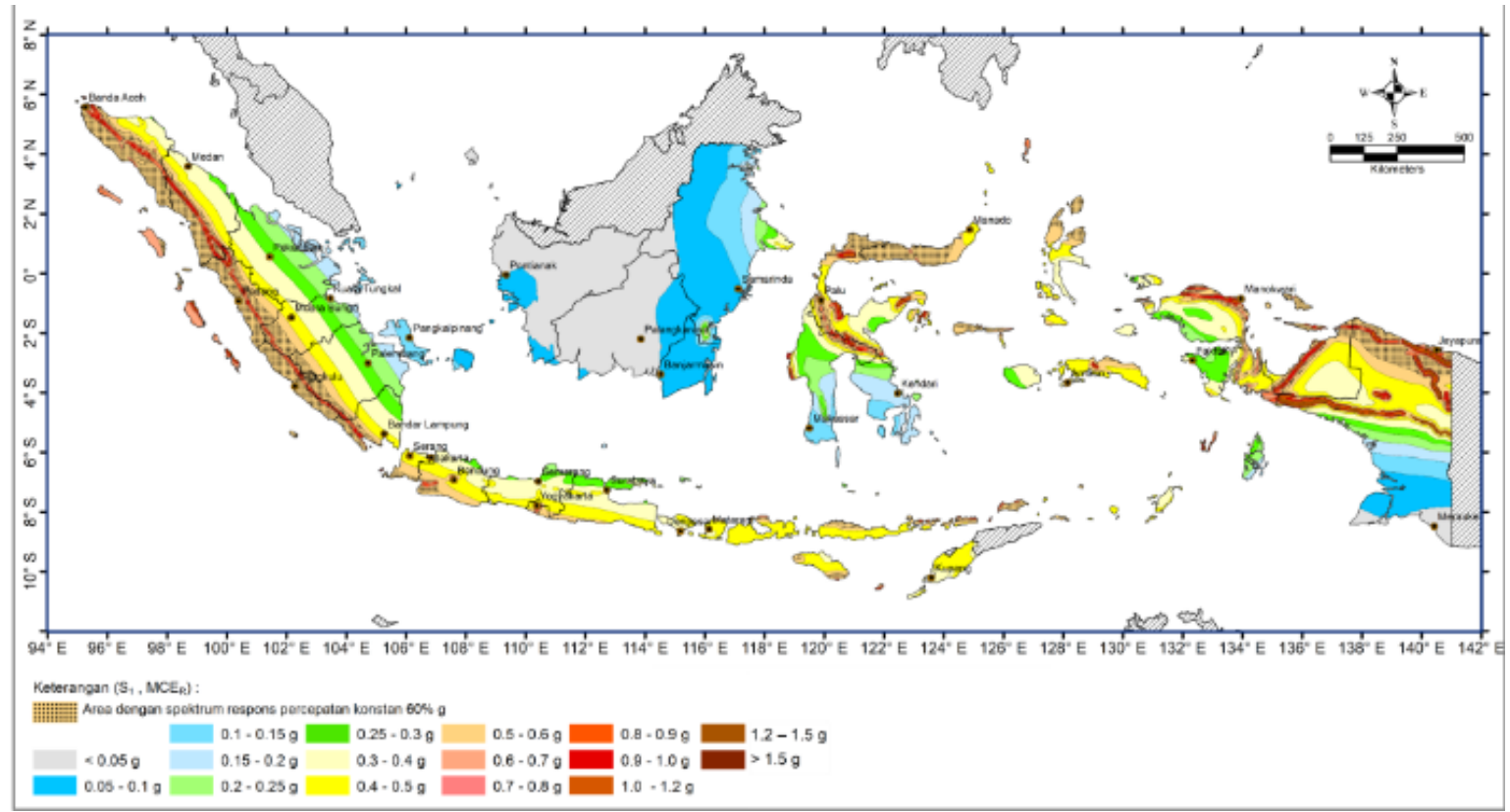

Gambar 5. Peta MCR-E periode panjang ( $T=1$ detik)

(Sumber: Anonim, 2012) 


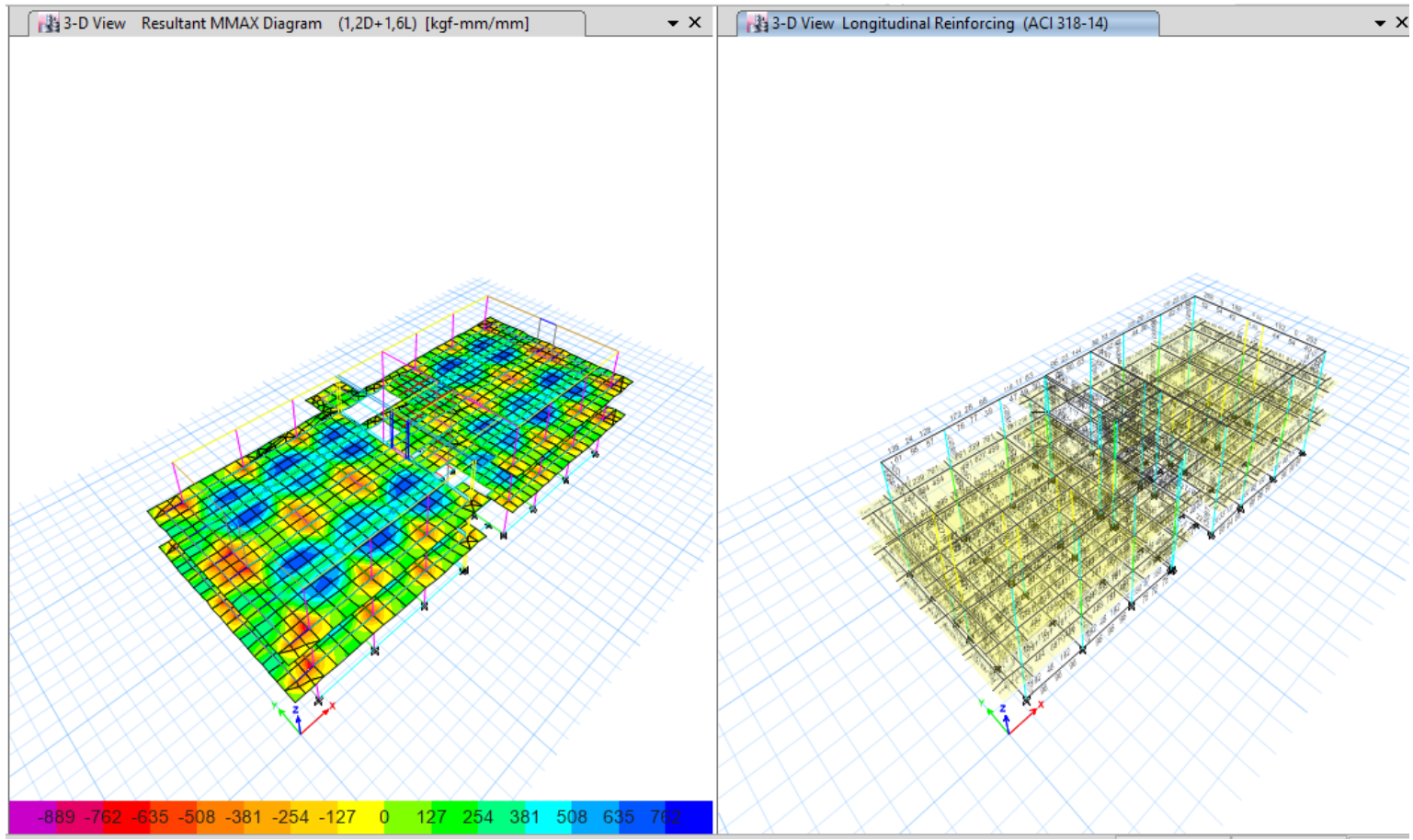

Gambar 6. Hasil Pemodelan Gedung Eksisting

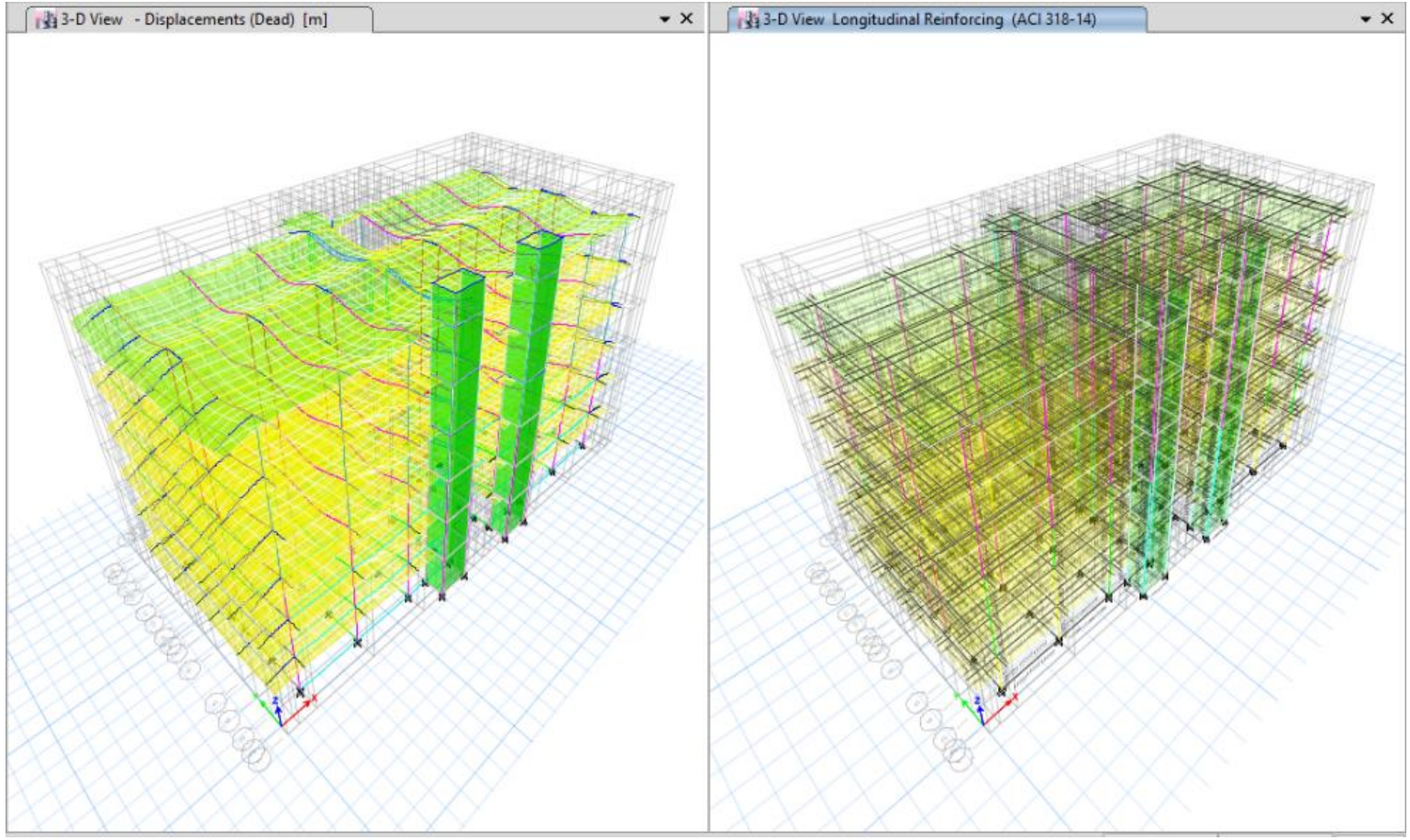

Gambar 7. Pemodelan 3D gedung Perkuliahan Fakultas Teknik UNEJ 


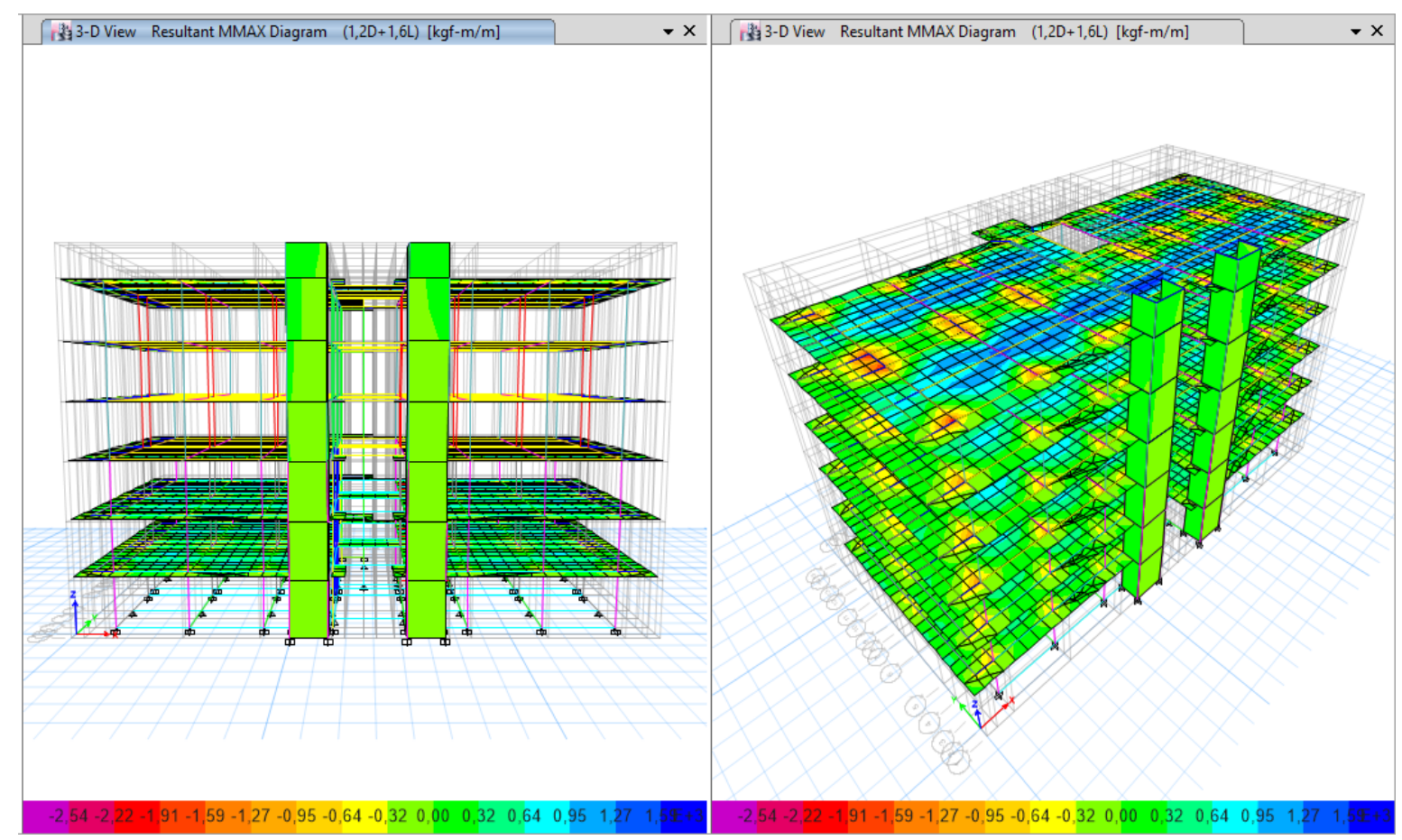

Gambar 8. Shell forces gedung Perkuliahan Fakultas Teknik UNEJ

\subsection{Pemeriksaan Simpangan Antar Lantai}

SNI 1726, pasal 7.12.1 telah mengatur perhitungan nilai simpangan antar lantai, untuk struktur dengan dinding geser dapat dihitung dengan perumusan berikut ini, $\Delta$ ijin $=0.007 \mathrm{x}$ hsx $=0.007 \mathrm{x}$ $4500=31.5 \mathrm{~mm}$. Hasil simpangan antar lantai yang terjadi dari program bantu analisis struktur yang dapat dilihat pada Tabel 5.

Nilai simpangan maksimum masih dibawah simpangan ijin $(10.2 \mathrm{~mm}<31.5$ $\mathrm{mm})$.

\subsection{Pemeriksaan Integritas Struktur}

Integritas struktur ditinjau untuk memeriksa bagaimana kondisi struktur akibat penambahan lantai. Integritas struktur diperiksa dengan meninjau rasio tegangan yang terjadi pada kolom. Dengan menggunakan rumusan (1) hingga rumusan (4) diperoleh nilai $\Psi=-0.97$, nilai integritas masih tergolong aman dengan kriteria $-1<$ $-0.97<1$ (Arfiadi, 2016).

\subsection{Evaluasi Akibat Penambahan Lantai \\ Perbedaan gaya-gaya yang terjadi antara gedung eksisting dengan gedung rencana disajikan dalam Tabel 6.}


Tabel 5. Simpangan antar Lantai Gedung Rencana

\begin{tabular}{lccccccc}
\hline \multirow{2}{*}{ Story } & Label & $\mathrm{UX}$ & $\mathrm{UY}$ & $\mathrm{UZ}$ & $\mathrm{RX}$ & $\mathrm{RY}$ & $\mathrm{RZ}$ \\
\cline { 2 - 7 } & & $\mathrm{mm}$ & $\mathrm{mm}$ & $\mathrm{mm}$ & $\mathrm{rad}$ & $\mathrm{rad}$ & $\mathrm{rad}$ \\
\hline LMR & 151 & -0.386 & 10.202 & -1.613 & -0.000551 & -0.000022 & -0.000001 \\
Atap & 127 & -0.314 & 8.991 & -34.999 & -0.006888 & -0.01401 & -0.00001 \\
Lt. 6 & 127 & -0.226 & 6.594 & -34.807 & -0.004618 & -0.014463 & -0.000009 \\
Lt. 5 & 127 & -0.145 & 4.421 & -34.11 & -0.005286 & -0.014547 & -0.000006 \\
Lt. 4 & 127 & -0.085 & 2.607 & -32.901 & -0.0047 & -0.014489 & -0.000004 \\
Lt. 3 & 127 & -0.04 & 1.227 & -17.227 & -0.004024 & -0.007858 & -0.000002 \\
Lt. 2 & 126 & -0.011 & 0.33 & -8.419 & -0.004105 & -0.006098 & -0.000001 \\
Lt. 1 & 2 & 0 & 0 & 0 & 0 & 0 & 0 \\
\hline
\end{tabular}

Tabel 6. Perbandingan Gedung Eksisting dengan Gedung Rencana

\begin{tabular}{llcc}
\hline No & \multicolumn{1}{c}{ Keterangan } & $\begin{array}{c}\text { Kondisi eksisting } \\
\text { (Lantai 3) }\end{array}$ & Setelah Penambahan (6 Lantai) \\
\hline 1 & Gaya Normal (maks.) & $82612.36 \mathrm{kgf}$ & $231431.13 \mathrm{kgf}$ \\
2 & Gaya Lintang (maks.) & $17900.48 \mathrm{kgf}$ & $20123.39 \mathrm{kgf}$ \\
3 & Momen (maks.) & $20997.88 \mathrm{kgm}$ & $24693.89 \mathrm{kgm}$ \\
4 & Lendutan & $0.244 \mathrm{~mm}$ & $8.965 \mathrm{~mm}$ \\
5 & Simpangan antar Lantai & $8.25 \mathrm{~mm}$ & $10.2 \mathrm{~mm}$ \\
\hline
\end{tabular}

\section{SIMPULAN DAN SARAN}

\subsection{Simpulan}

Berdasarkan perhitungan diatas dapat disimpulkan bahwa gedung eksisting dalam kondisi mampu menahan perencanaan akibat penambahan lantai, yaitu dengan nilai simpangan antar lantai terbesar 10,2 $\mathrm{mm}$ masih dibawah $\Delta$ ijin $(31.5 \mathrm{~mm})$ dan nilai integritas struktur sebesar -0.97 (syarat $-1<-0.97<1)$.

\subsection{Saran}

Perlu dilakukan penyelidikan tanah dan pondasi pada gedung eksisting serta perencaan untuk pondasi pada dinding geser.

\section{DAFTAR PUSTAKA}

Anonim. (2012). SNI 1726:2012 tentang Tata Cara Perencanaan Ketahanan Gempa untuk Struktur Bangunan Gedung dan Non Gedung. Jakarta: Badan Standardisasi Nasional.

Anonim. (2013). SNI 1727:2013 tentang Beban Minimum untuk Perancangan Bangunan Gedung dan Struktur Lain. Jakarta: Badan Standardisasi Nasional.

Anonim. (2019a). SNI 1726:2019 tentang Tata Cara Perencanaan Ketahanan Gempa untuk Struktur Bangunan Gedung dan Nongedung. Jakarta: Badan Standardisasi Nasional.

Anonim. (2019b). SNI 2847:2019 tentang Persyaratan Beton Struktural untuk Bangunan Gedung dan Penjelasan. Jakarta: Badan Standardisasi Nasional. 
Arfiadi, Y. (2016). Diagram Interaksi Perencanaan Kolom dengan Tulangan pada Empat Sisi Berdasarkan SNI 2847:2013 dan ACI 318M-11. Jurnal Teknik Sipil, 13(4), 268-290.

Irawan, J. (2012). Kegagalan Struktur dan Penanganannya. Jurnal INTEKNA: Informasi Teknik Dan Niaga, 12(2), 103-108.

Krisnamurti, Wiswamitra, K. A., \& Kriswardhana, W. (2013). Pengaruh Variasi Bentuk Penampang Kolom Terhadap Perilaku Elemen Struktur Akibat Beban Gempa. Rekayasa Sipil, 7(1), 13-27.

Octora, D. D. (2019). Analisis Non-Linier Penampang Pilar Jembatan Beton Bertulang yang Terbebani Diperkuat dengan Jaket Beton. Jurnal JalanJembatan, 36(2), 77-90.

Saruni, C. V., Dapas, S. O., \& Manalip, H. (2017). Evaluasi dan Analisis Perkuatan Bangunan yang Bertambah Jumlah Tingkatnya. JURNAL SIPIL STATIK, 5(9), 591-602.

Soenaryo, A., Hidayat, M. T., \& Siswanto, H. (2009). Perbaikan Kolom Beton Bertulang Menggunakan Concrete Jacketing dengan Prosentase Beban Runtuh yang Bervariasi. Rekayasa Sipil, 3(2), 91-100. 